Article

\title{
Seeing the Dog: Naturalistic Canine Representations from Greek Art
}

\author{
Kenneth F. Kitchell \\ Department of Classics, University of Massachusetts Amherst, Amherst, MA 01003, USA; \\ kkitchel@classics.umass.edu
}

Received: 13 November 2019; Accepted: 10 January 2020; Published: 30 January 2020

\begin{abstract}
This study attempts to demonstrate that ancient Greek authors and vase painters (mostly of the late sixth and early fifth centuries) were well attuned to the many bodily gestures and positions exhibited by dogs in real life and utilized this knowledge in producing their works. Once this is clear, it becomes evident that the Greek public at large was equally aware of such canine bodily gestures and positions. This extends the seminal work on gestures of Boegehold and Lateiner to the animal world and seeks also to serve as a call for further study of similar animals throughout ancient Greek times.
\end{abstract}

Keywords: animal studies; dogs in antiquity; animals in antiquity; Greek vases; body language

Despite the recent increased interest in animal studies, the dedicated work of scholars such as Liliane Bodson, and the publication of several handbooks and guides to animals in Greco-Roman antiquity, there are still significant gaps in our knowledge of the role of animals in material culture. ${ }^{1}$ As Harden (2014, p. 24) recently pointed out,

Animals frequently go unrecorded in publications and museum captions ... [and] rarely are individual species indexed in publications ... The art of the ancient Mediterranean is replete with images of animals, and much Classical art features animals prominently, but there are very few modern scholarly works that seek to analyze the semiotics of the depicted animal. ${ }^{2}$

Until the recent increase in ancient animal studies, animals remained in the background, both literally and figuratively. Two possible reasons may account for why this has historically been the case. First, studying a culture such as that of the Greek city states, where the human form and human accomplishments reigned supreme, can easily make the world of the animal seem to be of the second order. When an archaeologist had a magnificent Doric temple to excavate, the preservation and study of faunal remains often took second place. Given limited funds, should one reconstruct this frieze or count the bones from mice who may have nibbled on offerings there ${ }^{3}$ Furthermore, and rather ironically, the ubiquity of animals such as dogs and horses in Greek art can render them too familiar, rather like the sponges, strigils, and aulos cases that hang on the walls of gymnasiums on Greek vases. Similar to these mundane objects, animals have become part of the background for many scholars.

1 Prof. Bodson's output has been prolific. Most notable for the current study are (Bodson 1980, 1983, 1990, 2000). Note as well the internet-based bibliography assembled by Thorsten Fögen, https://www.telemachos.hu-berlin.de/ esterni/Tierbibliographie_Foegen.pdf. Most recently, see (Campbell 2014; Fögen and Thomas 2017; Johnston et al. 2016; Lewis and Llewellyn-Jones 2018).

2 It is notable that Harden's excellent chapter barely mentions dogs. Haworth (2018), to the contrary, demonstrates that dogs' presence in courting scenes is an important visual metaphor for the foolish, lovesick erastēs.

3 The argument is not confined to Classical times. One wishes dearly that Evans had carefully cataloged bones from Knossos. Contrast, for example, the careful work done by van den Dreisch and Boessneck (1990) at Liston et al. (2018) in the Athenian Agora. 
Dogs are probably the second most depicted animal in Greek art, second only to the horse. For example, a recent search of the Beazley Archive Pottery Database (BAPD) from Oxford University shows that the term "horse" yields 1728 hits, whereas the term "dog(s)" yields 1620. Such numbers undoubtedly reflect the reality of life, namely that the wealthy, elite Greeks shown on so many vases could afford to breed and own the best examples of both animals. ${ }^{4}$ Dogs have been studied in the past, to be sure, in works such as those of Johnson (1919), Hull (1964), and others. ${ }^{5}$ Yet, such works have tended to concentrate on hunting or attempting to identify ancient breeds. The recent studies by Franco (2014), Neils (2014), and Petrakova (2015) are notable exceptions. ${ }^{6}$

The impetus for the present study arose while conducting research on animals in the Greco-Roman world, cataloguing appearances of dogs in Greek art. On numerous vases and grave stelae, I saw dogs in poses that were immediately familiar to me as a life-long dog owner. Yet, despite this fact, it became clear that, while dogs were omnipresent in ancient Greek art, they are frequently ignored when scholars describe or discuss the art.

The current study attempts to answer two questions: First, "Did Greek artists try to represent dogs in a naturalistic way that reflects a close study of the animal?" Second, "Does a study of these portrayals over time yield any conclusions concerning the role of the dog in Greek life?" What follows are initial findings, presented in hopes of starting a dialogue on the subject and of encouraging further, related research. As is often the case when one speaks of "the Greeks", the evidence is largely taken from Athenian sources. One must rely heavily on material objects from Athenian workshops due to their predominance among the material remains from ancient Greece. Likewise, the authors cited range in date from Homer to Aelian (second century CE). ${ }^{7}$ One would ideally wish for information only from texts contemporary with the artifacts, but it can reasonably be assumed that later authors on animals often preserve beliefs that existed previously in the folk lore of the Greeks. I will begin with an overview of the literary sources to demonstrate that the Greeks in general paid very close attention to the behavior of their dogs and will then attempt to demonstrate the extent to which this interest is paralleled in works of art.

\section{The Literary Evidence}

There is ample evidence in the Greek language itself, which, when paired with evidence from ancient Greek authors, makes it clear that the Greeks paid quite close attention to their dogs. We turn first to words employed for canine vocalizations. Most dog owners are quite familiar with the myriad barks, whines, and growls dogs emit and know how to interpret them. The excited bark of a dog welcoming his mistress home is never to be confused with the warning bark of a guard dog. We know that the Greeks were attentive to these sounds, for their language contains a fairly large number of words, usually onomatopoetic in nature, to describe them. A dog at the mock trial in Aristophanes'

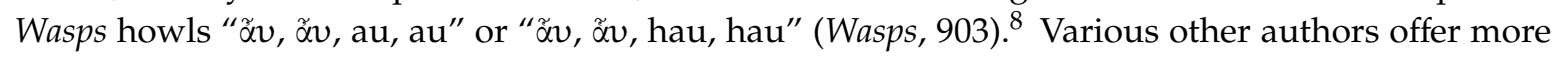
words. Barking is depicted in several ways, paralleling the multitude of English words for canine vocalizations such as bark, howl, whine, whimper, yap, and growl. Onomatopoetic Greek words include the following: " $\beta \alpha u ́, \beta \alpha u ́$ (bau bau); $\beta \alpha v \beta i \zeta \omega / \beta \alpha v \beta u ́ \zeta \omega$ (baubizō/baubuzō); and especially

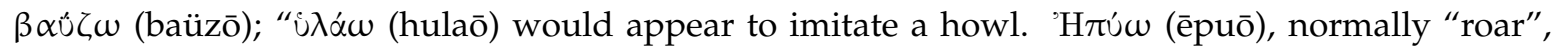
seems to indicate loud barking at Aristophanes (Eq. 1023). Other verbs include $\dot{\lambda} \lambda \dot{\alpha} \sigma \kappa \omega$ (hylaskō),

4 See (Harden 2014, pp. 33, 47; cf. Moore 2004, p. 60, n. 28) for references. The stray mongrel dogs who undoubtedly roamed Athens and any other location where they could act as garbage disposal units must have been numerous, but they are rarely depicted. On such pariah dogs, see (Serpell 1995a, b) in general and (Liston et al. 2018, pp. 58-59).

$5 \quad$ See (Johnson 1919, p. 209; Hull 1964, p. 13; Merlen 1971).

6 Petrakova (2015, p. 296), who states that in the late sixth and early fifth centuries "certain vase-painters of the Archaic period intentionally used dogs as rhetorical elements, for the visualization of emotions, metaphor or hyperbole, appears quite persuasive", informs much of what is to follow.

7 All dates are BCE unless otherwise stated.

8 The breathing is variously given as smooth or rough in the lexicons. 
$\kappa \lambda \alpha \gamma \gamma \alpha i v \omega\left(\right.$ klangainō), $\kappa \lambda \alpha ́ \zeta \omega$ (klazō), and $\theta \omega \dot{\sigma} \sigma \sigma \omega$ (thōussō). ${ }^{9}$ A dog who barks a great deal is

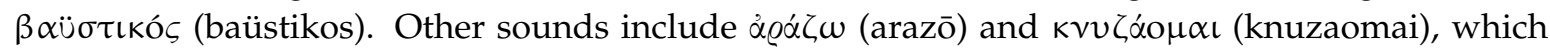
denote whining or whimpering. Such a variety of words for canine vocalizations indicates at the very least that the Greeks were in frequent contact with their dogs and that they felt it was important to be able to decipher their vocalizations. This interest in canine behavior is mirrored in the literature.

A passage commonly cited for the sympathetic portrait it paints of dogs is equally useful for demonstrating the interest the Greeks had in canine gesture and body language. This is the famous scene in the Odyssey (17.290f.) where Odysseus returns to Ithaca disguised as a beggar. He encounters his faithful dog, Argos, who now lies outside the city gates, exiled by the heartless suitors to sit on a

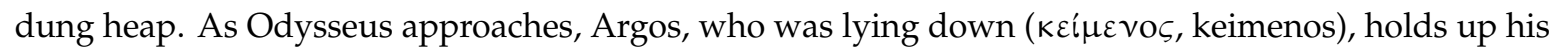
head and pricks up his ears (291). Then, once he recognizes his master, he wags his tail and drops his

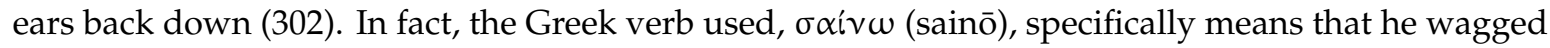
his tail and that he fawned on Odysseus (cf. Odyssey 10.214-17).

The scene shows that the author was well versed in canine body language and that he expected his audience to be equally well versed, for they would recognize the physical postures of Argos. A dog lying down, who still wishes to note what is going on around it, lies down with its head on the ground (Figure 1). When it notices something, it will raise its head and, as Homer points out, cock its ears in the direction of the object of interest. However, a dog who wishes to show submission in the presence of a more dominant animal or its master will flatten its ears back. After Argos has recognized Odysseus as his master, he assumes the appropriate position, laying back his ears and fawning.

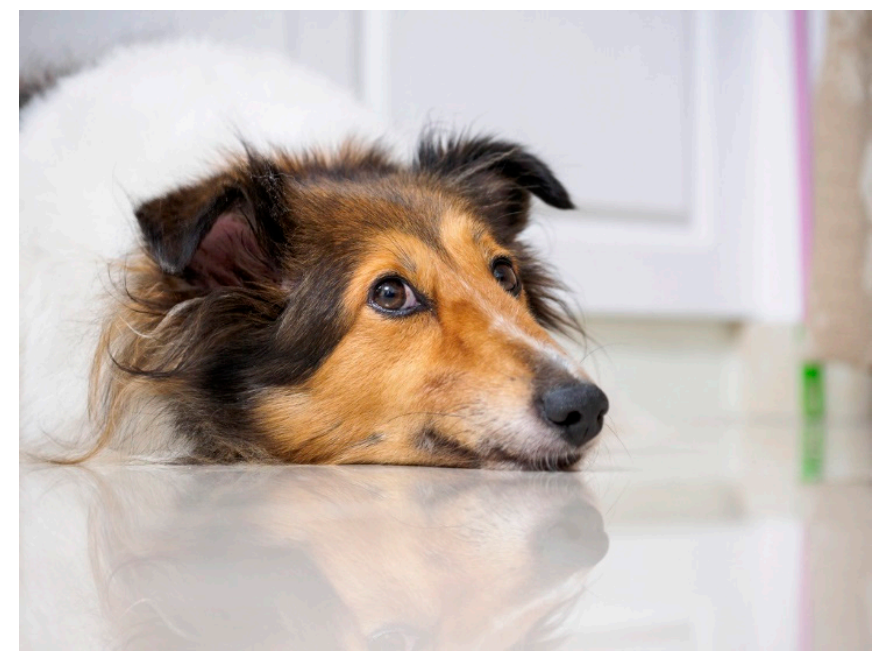

Figure 1. Source: Shutterstock, 473159719.

Xenophon's Cynegetica is a practical manual for young men on hunting with dogs. As is often noted, Xenophon pays careful attention to the breeds of dogs, listing their positive and negative traits. However, he is equally attentive of canine behavior and body language, especially as it indicates their potential as good hunters (3.1f.). He notes physical traits, such as head shape, but also reports on canine behaviors, using a rich Greek vocabulary that was surely used by breeders and buyers alike. Some dogs, he says, do not give any visible signs when on the hunt, while others move their ears, tails, or both. Some drop their tails and some even tuck them in between their legs (3.4-5). When tracking, well-bred dogs keep their heads down, lower their ears, and wag their tails. When they are near the hare, they should become more excited, showing this through movements of the head and eyes,

$9 \Theta \omega \dot{\sigma} \sigma \sigma \omega$ is Homeric and can also mean to cry out to the hounds. In English, foxhounds on the hunt are said to "cry out" when on the scent. Similarly, their handlers "cry out" to the dogs. 
the eyes moving up first toward the hunter (cf. 6.23) and then back to the hare's den. More on this eye movement below. Overall, at such a moment, the dogs should clearly be enjoying their work, and Xenophon even says (14.3) that they should "smile" ( $\varepsilon \mu \mu \varepsilon \iota \delta \iota \widetilde{\omega} \sigma \alpha \iota$, emmeidiōsai) (Figure 2).

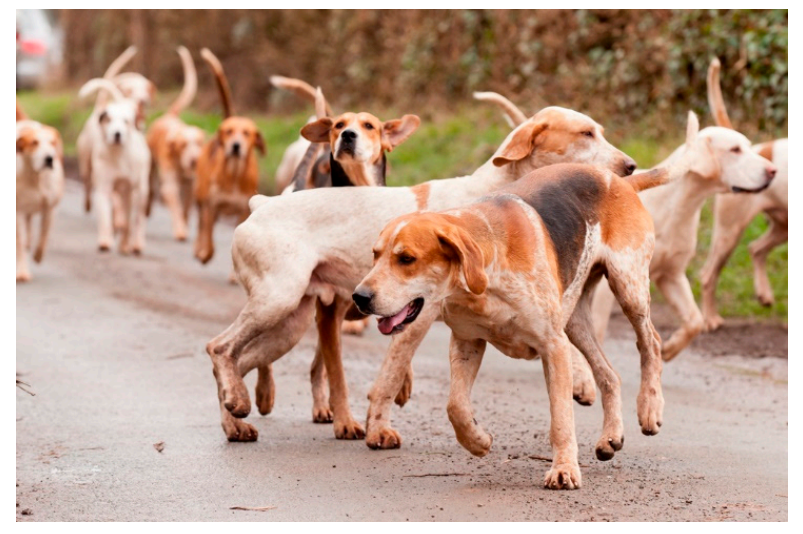

Figure 2. Source: Shutterstock 174654926.

The concept of a dog smiling brings to mind Labes, the dog put on trial in Aristophanes' Wasps, who grins ( $\sigma \varepsilon \sigma \eta \varrho \omega ́ s$, sesērōs) when brought out before the one-man jury. Most, if not all, modern scholars reading the play take this behavior at face value, perhaps thinking the dog is acting arrogantly. However, Labes is not smiling because he is arrogant or happy. To the contrary, he is nervous, because he has been caught stealing cheese and is now before the bar of justice. Aristophanes seems rather to be appealing to the audience's knowledge of a behavior known to many dog owners. The verb used by Aristophanes ( $\sigma \alpha i \varrho \omega$, sairō) specifically means to part the lips and show closed teeth. ${ }^{10}$ In canine behavior, it describes what today is commonly called the "smarl", a behavior undertaken to show deference to a higher ranking dog or human, often used when the dog is nervous or guilty. The dog's upper lips retract horizontally to reveal the teeth, but the mouth is not open. The dog commonly squints its eyes, turns its head, and lowers its ears (Figure 3). The more formal name for the behavior is either the "submissive grin" or "submissive smile."11 Additional pictures and videos of the behavior are readily found on the internet.

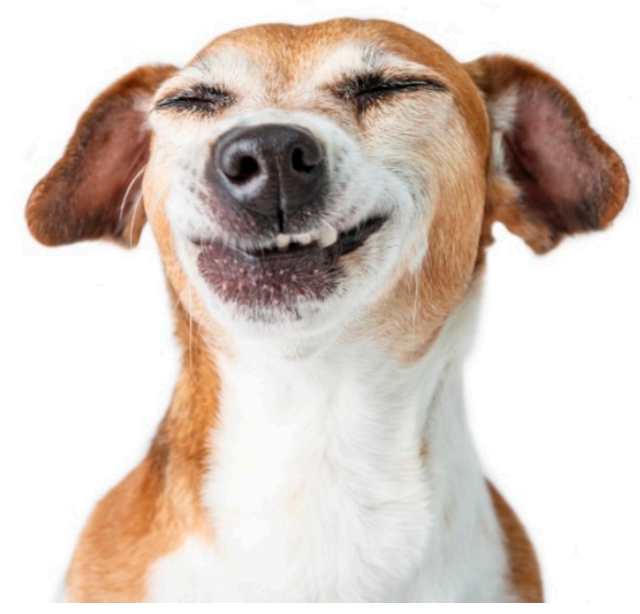

Figure 3. Source: Shutterstock, 723325606.

10 Several citations from other authors can be found in the major lexicons.

11 Fox (1970) surveys the behavior throughout the Canidae. For a complete description of the submissive grin, see (Simpson 1997, p. 455). 
Greek literature, then, helps us establish that the Greeks paid careful attention to the behavior and body language of their dogs, so much so, in fact, that a plethora of specific words existed for their various behaviors. This is hardly remarkable given the Greeks' devotion to pastoralism and the hunt. Such attention to behavioral detail could also help ensure that one bought a good hunting dog or companion from the breeder. ${ }^{12}$ Moreover, as any dog owner knows, being aware of the body language of these expressive animals helps one to train them. Finally, in a time and place where dogs roamed freely, long before a rabies vaccine had even been thought of, it was wise to know which dogs were approachable and which were not. ${ }^{13}$ Having determined this much, we can now investigate to what extent Greek works of art demonstrated the same level of interest and whether there is any change in this sort of representation over time.

\section{The Dog in Greek Art}

Seth Pevnick recently stated in an admirable article that "although dogs appear with great frequency on painted pottery, they often escape mention, even in basic descriptions of vases; canine iconography still awaits a comprehensive study" (Pevnick 2014, p. 156). Yet, a close study of how the Greeks chose to depict their dogs is very revealing. It provides insight into the human/canine relationship of ancient Greece and, in so doing, can illuminate certain aspects of ancient Greek life. It is best, however, to begin with a survey of how the dog had been depicted before the move toward accurately depicting their behavior arose in the late sixth and early fifth centuries.

The dog was probably the first species of animal domesticated by humans. ${ }^{14}$ The exact time and place are constantly debated, but it seems that "proto-domestication", a sort of symbiotic living arrangement, may have occurred as early as 35,000 BP. ${ }^{15}$ One set of experts characterizes the next phase as follows: "Archaeology has defined the period in which the first dogs appeared as the Late Glacial time bracket of between 18,000 and 10,000 BC" (Horard-Herbin et al. 2014, p. 23). ${ }^{16}$ Clutton-Brock, an expert on domestication issues, states that the earliest archaeological evidence of a truly domesticated dog comes from the Late Paleolithic in Germany and dates to about 14,000 BP (Clutton-Brock 1995, p. 10). Touchingly, an inhumation of an elderly human with its hand on the skeleton of a puppy was found in Israel and dates to 12,000 BP (Davis and Valla 1978). The earliest representation of a dog near actual Greek territory of which I am aware is one from Pietrele much further north in Romania. The small clay sculpture, apparently of the Late Neolithic/Chalcolithic age, depicts a recumbent dog, curled up and resting (Orphanidis 1998, chp. 3, no pagination is given).

In pre-Hellenic times, the dog is occasionally found in Cycladic art but is more common in Minoan art (Broodbank 2000, p. 309; Hood 1978, pp. 33, 90). Two examples, from Mochlos that depict dogs are of interest (Hickman 2011, passim). ${ }^{17}$ The first is the so-called "Dog Diadem", which dates to Early Minoan times and depicts four dogs incised in outline on a gold band with dot repoussé filling in the outlines (Heraklion Museum 269). Another find from the same burial area that contained the diadem shows a long, angular dog reclining on the lid of a jar. ${ }^{18}$ Minoan/Mycenaean seal stones often depict dogs in a variety of situations. 19 When the dog appears with humans, it is commonly,

12 On breeders of ancient Greek dogs, see (Hull 1964, pp. 39-43) and cf. horse breeding as described by Moore (2004, pp. 54-56).

13 On rabies, see, e.g., (Aelian NA 12.22 and 14.40; Pliny HN 8.152-53; King 2004).

14 On the domestication of the dog, in addition to what follows, see (Morey 1994; Lobell et al. 2010) and the thorough study of (Derr 2011).

15 See (Galibert et al. 2011, p. 191).

16 They also discuss the morphological changes that occurred as the wolf became the dog.

17 See especially figs 10.1-10.4 and 95-96 for other representations in Minoan and Cycladic art.

18 See (Johnson 1919, pp. 210-11; Hickman 2011, fig. 10.6). A similar vessel was later found at Zakro. See further, (Wiencke 1986, pp. 86-87).

19 A search of the Corpus of Minoan and Mycenaean Seals (CMS) on the Arachne website yields 279 results, although the figures are often quite schematic, and the CMS tends to identify these as "Löwe oder Hund". Some seem more clearly canine. To identify a few: CMS-VI-357-1 (with collar) and CMS-XI-008b-1 (canine ears). Hunts: CMS-VI-180-1, CMS-VI-400-1 CMS-VI-153b-1. Some show a female suckling her pup: CMS-II, 8-289-1, CMS-VII-066-1(with a collar and 
but not exclusively, in a hunting scenario (Marinatos and Morgan 2005, pp. 119-20; Evans 1921, pp. 523-24, figs. 469-71). ${ }^{20}$ The Mycenaeans are the first true Greeks to depict the dog, doing so mostly in hunting scenes. ${ }^{21}$ Dog drivers (kunagetai) are listed on a Linear B tablet, a term perhaps referring to the hunt (Ventris and Chadwick 1973, no. 132), and there are instances of dog burials with humans. Hamilakis (1996) believes that dogs were included as an offering for the human to indicate social status as evinced through hunting rather than out of any sentiment toward the animal. ${ }^{22}$ Indeed, a hallmark of canine burials at the time is the apparent lack of care taken when including the dog's body in the tomb, for it is carelessly tossed into the grave and not laid out with any care (Day 1984, p. 26). Other Mycenaean representations also reinforce a connection with the hunt. A fragmentary, Late Helladic IIIB krater in the British Museum $(1899,1229.135)$ depicts a bull hunting scene in which a man holds two dogs on leashes and the well-known, reconstructed fresco from Tiryns depicts dogs attacking a boar in the flying gallop characteristic of the time. The bulk of evidence, then, seems to indicate that Minoan and Mycenaean dogs were primarily valued for their usefulness in the hunt, and one notes a lack of sentiment or closeness with the animals (Hickman 2011, p. 96). I know of no scene in which a dog and a human are shown together in what we might call a domestic scene. This would only occur later.

Protocorinthian art also tends to depict dogs in animal friezes and in hunting scenes and not in domestic ones. The dogs are rendered somewhat naturalistically but tend to be shown in a conventionalized running pose with their tails extended or curled. ${ }^{23}$ Athenian Geometric vases depict dogs, but the style of the art of the times does not lend itself to more detail than the dogs' basic presence. $^{24}$ Coldstream (1994, fig. 3) published a very early image of two dogs pursuing a hare from a Late Geometric IIb amphora. This drawing, based on the badly faded glaze images, clearly depicts speed, but there is little realism attempted. A Late Geometric Boeotian kantharos in the British Museum, dated to ca. 700, $(1910,1013.1)$ shows two dogs leaping on the hindquarters of a boar (?) while a man with a spear attacks it from in front. We thus see once more the dog as primarily a living tool to be used in the hunt. ${ }^{25}$ Archaic and high Classical art begins to depict canines with increasingly greater attention to their naturalistic behavior. While this increased attention to depicting the dog naturally may be partially due to a general artistic move to naturalism, it also seems to follow a period in which the dog, as it were, is moving in from the periphery of human life (e.g., in the wild, on the hunt) and into its midst, becoming more entwined in the daily life of the Greeks. ${ }^{26}$ The Chigi Olpe (mid seventh century, Villa Giulia, 22679), which has two friezes containing dogs, offers an example of both artistic approaches on the same vase. The third frieze depicts dogs, unaccompanied by a human, stalking goats. These dogs are in what amounts to a repetitive frieze, nose to tail. In its lower frieze, however, the vase has a vivid depiction of a hare and vixen hunt in which one dog is shown in a very naturalistic pose, crouched and eager to pounce, but held back by its master. ${ }^{27}$ This appearance of both stylized and more naturalistic dogs on the same vase can serve, therefore, as a visual bridge linking earlier depictions of the dog with the more naturalistic dogs to come.

lead?). Other examples include: dog scratching (see below) on CMS-I-255-1, CMS-I-256-1, CMS-II,6-076-1 et al.; head of a $\mathrm{dog}$, resembling a Molossian/mastiff-type breed, CMS-II,5-299.1 and 300-1 and CMS-II,5-299-1; a pair of dogs of the hunting type, CMS-VS3-396-1; play position (see below) CMS-VII-216b-1; accompanying a warrior or hunter, CMS-II,8-236-1.

20 Some excellent examples of Minoan and Mycenaean images of dogs can be found in (Papageorgiou 2008, pp. 9-37).

21 A Late Helladic hound's head rhyton in the Ashmolean Museum, AE.298 is a notable exception.

22 But cf. Day (1984, p. 26), who notes the parallel to the table dogs $(\tau \varrho \alpha \pi \varepsilon \zeta \tilde{\eta} \varepsilon \varsigma)$ Achilles sacrifices at the Grave of Patroclus (Iliad 23.171-77).

23 E.g., British Museum 1889, 0418.1 (the Macmillan Aryballos); Cleveland Museum of Art, 341.15; Taranto Museo Archeologico Nazionale, 4173; Louvre, CA3744A.

24 See (Boardman 1966, p. 2; Day 1984, p. 24; Johnson 1919, "Portrayal of Dogs", p. 211; Rombos 1988, pp. 222-26).

25 Schmölder-Veit (2008) describes this development well.

26 This change is traced in (Kitchell 2004). See also (Franco 2014, pp. 17-53; Petrakova 2015, p. 292 with notes, who lists several categories of canine and human interaction).

27 See the careful reading of the vase by Hurwit (2002) who, however, gives only passing notice to the dogs (pp. 8-9). For the friezes in question, see his figs. 6-7 and (Rassmussen 2016, figs. 1-4). 
It is in vases of the Classical period, especially those of the late sixth and early fifth centuries, that a tendency toward depicting naturalistic canine behavior flourishes. As John Boardman has said, "Greek artists were hardly less observant of the animal kingdom than they were of man." 28 We know that ancient artists were very attentive to animal life. Pausanias (1.29.15) proclaims Nikias the greatest painter of animals in his time. Kalamis (fl. 475-450) was famous for his horses, Myron (fl. 480-455) renowned for a sculpture of a cow, and Strongylion (fl. last quarter fifth century) for his horses and oxen. ${ }^{29}$ Second, the literary and artistic evidence supports the thesis that over time the dog moved from being merely a domesticated animal, coexisting with humans as oxen or sheep do, to become an integral part of Greek life. ${ }^{30}$

Although the dog is ubiquitous on vases and grave stelae, it is usually given very cursory attention. Consider the official description of this scene from a vase numbered in the Allard Pierson Museum collection (inv. no. 14.225) attributed to the Tyszkiewicz painter (Figure 4): "man in pleated clothes leaning on stick before ithyphallic herm, with dog approaching from behind" (trans. B. van Oppen). As it stands, this is an accurate description. Yet, as we will see below, there is much more going on here than the dog being an extra in the scene. Moreover, this is far from an isolated incident. A perusal of the descriptions of vases in the Beazley Archive depicting dogs shows that most offer a terse "dog" or "dogs" to describe scenes where a knowledge of canine body language is depicted by the artist and contributes to the tone of the scene.

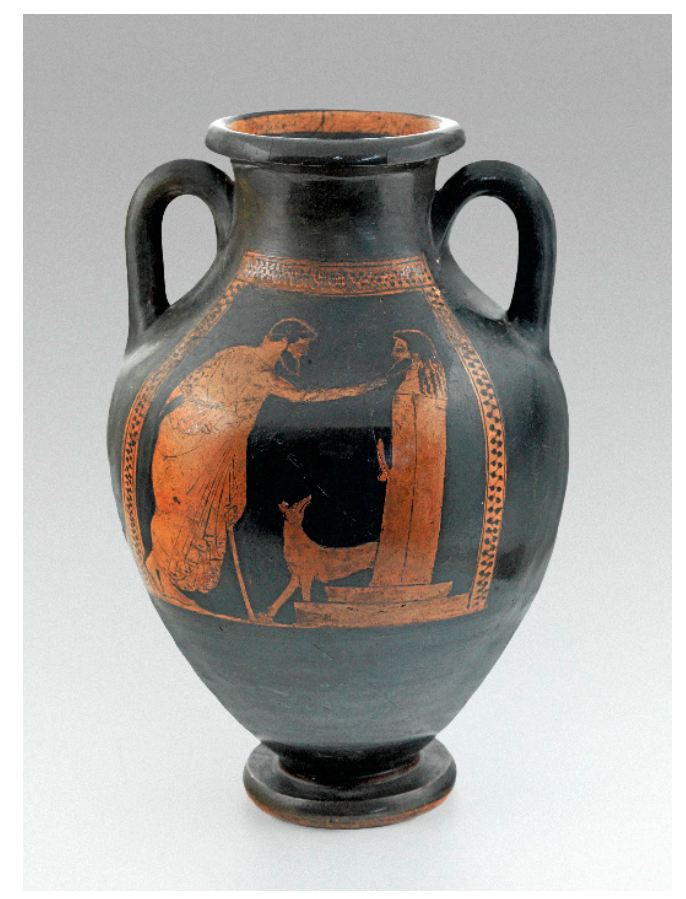

Figure 4. Bearded man with dog in front of ithyphallic herm (APM inv. no. 14.225); amphora; Table 500. Photo by Stefan van der Linden; image courtesy of the Allard Pierson Museum, Amsterdam.

It is important to state that, even at the height of the red figure period, some vases bear images of dogs who are indifferently rendered. A common example of this occurs in scenes of dogs attacking

28 Quoted by Harden (2014, p. 24).

29 Richter (1970) collects the evidence for each. Kalamis: pp. 158-60 with references; Myron: pp. 160-66; Strongylion: pp. $188-89$.

30 Cf. (Kitchell 2004). 
Actaeon where the dogs are often stiffly drawn. ${ }^{31}$ Other painters choose to show dogs merely as visual fillers, mandatory presences in scenes such as symposia or the departure of a warrior. However, there are an impressive number of vases that not only demonstrate the artist's skill with a brush but also testify to his interest in depicting canine behavior accurately.

\section{Canine Body Language in Greek Art}

Alan Boegehold and Donald Lateiner have demonstrated clearly that the ancient Greeks paid very close attention to interpersonal, nonverbal communication among humans and have set forth numerous examples of how this is portrayed in art through posture, gesture, and facial expression. I believe the same technique can be applied to certain vase depictions of dogs, for just as depictions of humans on vases do not allow us to hear what they are saying, depictions of dogs do not allow us to hear the myriad sounds they produce. However, just as with humans, dogs regularly exhibit an elaborate vocabulary of gestures and postures that are very informative as to their intentions and moods. Some of these gestures are to be found in wolves and other canids, but the dog is special. After years of what might be called social evolution, that is, changes brought about by living dependently with humans, they have developed a panoply of gestures and body language used specially to communicate with their masters (Bradshaw and Nott 1995, pp. 115-30).

It is of interest to point out that some of these gestures and postural positions were already in place by the time Greek artists began depicting dogs, but, to answer the second question posed in the introduction to this piece, one can trace changes over time in these representations. This is linked to a clear, steady change in the positive and negative attitudes toward dogs throughout Greek culture (Kitchell 2004, pp. 181-86). Most recently, Franco (2014, pp. 17-53) affirmed this dual attitude toward the animal and how it affects our study of women in ancient Greece. However, another division seems more basic, viz., that between the working, generally outdoor dog and the dog kept at least partially indoors, which served many of the functions of a pet. This duality is very clear as early as Homer. As mentioned, Argos was known for his loyalty and his past excellence in the hunt. The dogs guarding Eumaios's pigs are compared to wild beasts (Od. 14.21). However, Odysseus (Od. 17.309-10) also scornfully mentions useless dogs kept solely to serve as showpieces for their masters (Scodel 2005, pp. 401-8). Homeric dogs are routinely said to prey on corpses lying outside of the city of Troy, and one thinks thus of feral dogs. In contrast to these, Priam speaks of the useless dogs who share his table in his house. Nevertheless, he fears they too will revert to savagery and defile his body when he is dead (Il. 22.75).

This particular duality never vanishes in Greek thought or art. Consider Thucydides' statement (2.50) that the plague of 431/30 was especially ill omened, because even the dogs and vultures did not feast on the dead bodies. Because we know that the population of Attica was taking shelter within the city walls, this means that Thucydides is surprised that the dogs of the city did not feast on the bodies of the dead-a statement demonstrating that the positive/negative duality existed to his day. However, despite this lingering duality, it can be demonstrated that, at least by the late sixth and early fifth centuries, there arose an increased tendency to see the dog as more than an animate tool, useful merely as a hunter or guard. To put it simply, while dogs certainly continued to hunt and guard flocks or herds, by the late sixth to early fifth centuries, the dog had become more fully integrated into the social pattern of Greek life. This change can be demonstrated and traced through artwork.

One of the first, and clearest, indications of a change in attitude toward the dog is seen on the François Vase (570-560?). Among the vase's many scenes is one of the Calydonian Boar Hunt, and all seven of the dogs attacking the boar are given names. The names are Egertēs, (Rouser); E[u]bolos (Lucky);

31 Black figure: Athens, National Museum 489. Red figure examples include Copenhagen, Thorvaldsen Museum, 99A and a krater attributed to the Pan Painter, Museum of Fine Arts, Boston 10.185. A fragmentary mug in Wurzburg, Martin von Wagner Museum H5356, shows more animated dogs, even delineating one as female. 
Korax (Raven); Labros (Violent/Greedy); Marpsas (Grabber); Methepōn (Tracker/Pursuer); and Hormenos (Rusher/Charger). There is irony in the last instance, for Hormenos has been disemboweled and his rushing days are over.

These dogs are clearly still primarily valued for their hunting ability and courage, but the Greeks now think they are individualistic enough to warrant names and these names are worthy to be set alongside those of heroes. As I hope to show below, the hunting dog next moved from this baseline level of value to a position of outright affection-out of the pasture, hunting grounds, and kennel, and into the symposium and gymnasium (on which, see below). Moreover, as it came more and more into the daily life of the Greeks, it was observed more closely by artists. Nor must we ignore the customers of these potters and painters who clearly paid good money for pots depicting their canine friends. As a result, there is a profusion of evidence to study.

Greek dogs served, as they generally do in most cultures, a variety of functions. These included guarding, hunting, and serving as companion animals. In art, we less frequently see the large dog usually called a Molossian, which was used as a herding or guard animal. The most famous of such representations is the dog guarding the fourth-century tomb of one Lysimachides of Acharnai in the Athenian Kerameikos. Note that Molossians are not, to my knowledge, shown in indoor scenes. They seem to have a status equivalent to that of the guard dogs of Eumaeus, although in this instance Lysimachides thought enough of this particular dog to set him as an eternal guard over his remains. A pelike by the Dwarf Painter dating to 475-425 and in the Museum of Fine Arts, Boston (R426, BAPD 214151) shows a Molossian led by a dwarf. The human's head rises barely above the animal's back.

The small furry dogs usually called Maltese are also companion animals, found mostly, but not exclusively, in the women's quarters and with children. Maltese are common on the choes given to children at the Anthesteria. Perhaps these cuddly dogs were given to children during this festival, along with the other small animals we find on the vases, such as birds, goats, and fawns. However, we must point out that this type of dog was often associated with grown males as well. ${ }^{32}$ It remains for another study to trace the types of dogs Athenians possessed as possible age/rite of passage markers throughout the course of their lives.

It does seem clear, however, that when young men left the world of the women's quarters and entered into the world as ephebes, they were expected to take up the hunt, and this required hunting dogs. Xenophon pointedly claims that hunting skills are necessary to hone not only martial skills but even such skills as proper thinking, speaking, and behavior. It was so important that he says, "The first thing a male should do, upon exchanging childhood for manhood, is to take up hunting with dogs, and, after that, the other kinds of education." (Cyn. 2.1). One might think that these dogs only interacted with the males during the hunt, but the visual evidence is to the contrary, for hunting dogs served as close companions to youths in Athens, participating in virtually all aspects of their lives during the Classical period.

The dog is very often depicted in scenes of homoerotic courting, where young males were courted by older males, often in the gymnasion. Sometimes they are simply in the picture, part of Athens' canine landscape. However, at other times, they are intimately associated with the practice of male homosexuality prevalent in Athens at the time. In this practice, the older lover (erastes), presents his beloved (eromenos) with money or a gift, the entire scene often being accompanied by a gesture that clearly indicates expectations of sexual favors in return (von Reden 1995, pp. 120-23, 195-216). ${ }^{33}$ That gift often consists of animals, such as a fox or hare, which were captured with the help of a $\mathrm{dog}$, or sometimes, it is the dog itself. Note the prevalence of collars and leashes on these animals,

32 Bussitil (1969, pp. 88-93) offers an overview of the animal. See also (Brewer et al. 2001, pp. 85-86; Moore 2008, pp. 16-18).

33 Although Reden generally ignores the animals as gifts, as does Percy (1996). Dover (1989, p. 92) and Younger (2005, p. 70, s.v. "Love-gifts") offer a small list of animal gifts. Examples of such scenes can be seen on vases: Munich, Antikensammlungen: 2290A (BAPD 9533) 575-525; Vatican City, Museo Gregoriano Etrusco Vaticano: 352 (BAPD 301064) 575-525 (on which, see below); Providence (RI), Rhode Island School of Design: 13.1479 (BAPD 301624). 
telling us for certain that the dogs were not free roaming, but were kept under control of these upper class citizens, both to insure against losing the animal and to keep it from indiscriminate mating with free-roaming mongrels, which would dilute blood lines.

Dogs are also commonly present indoors at the "cocktail party" known as the symposium, held in a private space reserved for Athenian males. ${ }^{34}$ These dogs are identical in shape and size to the dogs we see in hunting scenes. Whether they are true pets (defined as an animal kept by humans for no practical purpose but rather for the pleasure of their company) or whether they might be simultaneously hunting and indoor dogs is unimportant. What is important is the intimacy that they share with their masters in these scenes where they lie beneath the symposiast's couch and even snatch meat from the revelers. Contrast, for example, Priam's dogs (mentioned above) who lay beneath his table, to be sure, but who also retained more than a little of their untamed natures.

Dogs were often present in the military life of an ephebe as well. They commonly accompany their masters in what are taken to be scenes of training, and they are almost a stock character in the many vases depicting the farewell of a warrior. ${ }^{35}$ They even seem to appear in military contexts (Mayor 2014, pp. 286-87). ${ }^{36}$ They are also seen amid competitions and festivals. In short, wherever the life of an Athenian aristocratic youth took him, he went there accompanied by his canine companion.

Nor were dogs absent elsewhere throughout the polis. Stelae regularly bear images of dogs, and the vases make it clear that dogs would loiter near shops, such as the butcher's shop and the fishmongers. ${ }^{37}$

To sum up, then, we see the dog present in all aspects of Athenian life, and they are regularly shown in close interaction with a human and not merely as a sort of background filler. To provide some sort of touchstone for this, note that Greek vases show adult males interacting much more with dogs than with human children. These facts establish the "what" of the matter, i.e., the fact that the Greeks and their dogs lived intertwined lives, but we must turn now to the "how" — the manner in which Athenian artists chose to show the animal.

Most basic vase descriptions will note the presence of a dog in the scene but will do so only with a terse phrase such as "dog". However, if one spends time looking at the way the dogs are depicted, it is clear that the artists were at pains to include natural, observed canine behaviors in their scenes, behaviors that are the same ones we can see today on a daily basis, for they are part of the dog's evolved behavior and can readily be compared to those depicted in Figure $5 .{ }^{38}$

34 E.g., a psykter from the Basel market, (BAPD 718) 550-500 (cf. Moignard 1982); British Museum B679, 524-475 (BAPD 4824), where the dog is female; Private collection, 550-500 (BAPD 16042; Museo Nazionale Tarquiniese RC6823. 528-475 (BAPD 7648); Louvre, Campana Collection F2 (BAPD 10707); Tübingen, Eberhsard-Karls Univ., Arch. Institute S101391 (BAPD 11642) where the dog is a maltese and seems to share the couch with the youth.

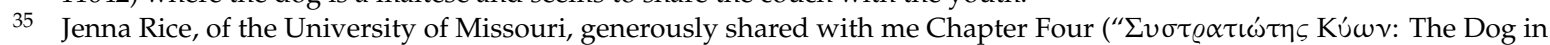
the Ancient Greek Military") of her soon to be submitted dissertation, where she categorizes over 100 departure scenes depicting canines. Note especially: Market, 550-500 (BAPD 9032300); Bologna, Museo Civico Archeologico 24 (BAPD 13161) 525-475, where a man holding two spears seems to reach out to pet the dog; Geneva, Musee d'Art et d'Histoire: 14989.1937 (BAPD) 550-500. Cf. (Moignard 1982, Pl. 10a), by the Acheloos Painter, who seems to have been fond of portraying dogs.

36 Examples include the following: Kurashiki, Ninagawa, 23 (BAPD 7307), 575-525; Brussels, Musees Royaux, Unknown, Somzee Collection, Brussels, van Branteghem, A1375 (BAPB 3277); Cleveland Museum of Art, 29.135, 525-475 (BAPD 759). It is often difficult to differentiate scenes of military training from certain athletic competitions.

37 On stelae, see (Ridgway 1971; Taliano 2012). Butcher: Heidelberg Univ., 253, Olpe, 525-475, Leagros Group (BAPD 10598) 550-500. Fishmonger: Berlin Antikensammlung F1915 (BAPD 3032328). It is just possible each is a sacrifice scene, but we can imagine dogs frequented these as well.

38 My thanks to Chris Crawford of Dogs for Defense K-9 for granting permission to use this chart. Further information may be found at www.dfdk9.com. 


\section{DOG TO ENGLISH TRANSLATION CHART}
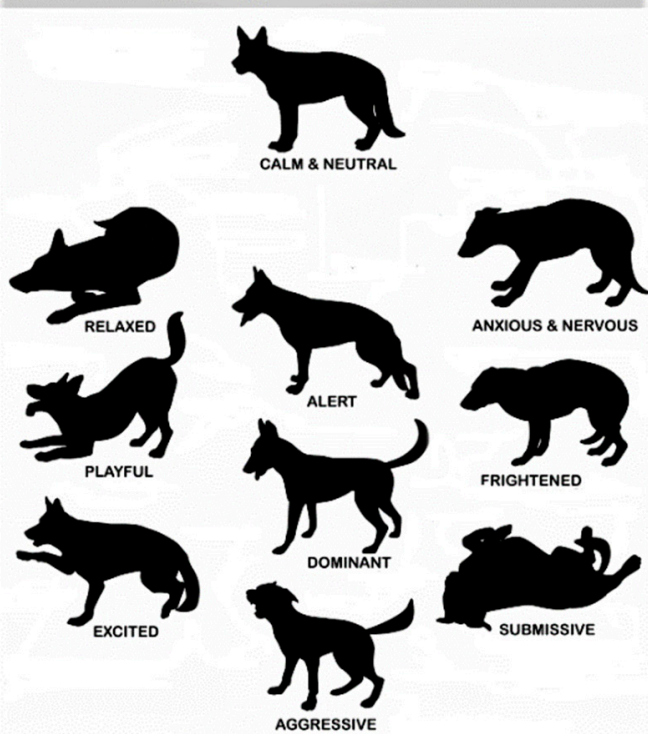

ANXIOUS \& NERVOUS

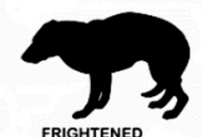

FRIGHTENED

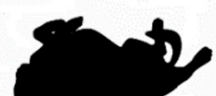

SUBMISIIVE

SUBMISSIVE

COPYRIGHT 2010. DOGS FOR DEEENSE K-9 - ONLINE AT WWW.DFDK9.COM

Figure 5. Dogs for Defense, www.DFDK9.com. Image courtesy of Chris Crawford.

As stated above, some dogs are drawn rather indifferently even in the Classical period. ${ }^{39}$ In these cases, not a great deal of attention is given to the dogs' body language, and it is hard to read much into the depiction. However, far more often, the dog is carefully drawn and, at times, is actually the focus of the scene, giving it meaning and poignancy. Certain instances involve solitary or static activities. Even when a dog is merely standing (Figure 6), we can read its body language (cf. Figure 5, "Calm \& Neutral"). Its body is relaxed, and its ears are loosely erect. In some relaxed dogs the tail is lowered and loose, but the curled tail on Greek hunting dogs is probably a breed trait and is always shown as curled up over the back. Sometimes only a simple action is depicted, such as scratching (Figure 7). However, comparison with an actual photograph of a dog performing this act shows that it was often drawn by the Greeks based on careful observation (Figure 8). ${ }^{40}$

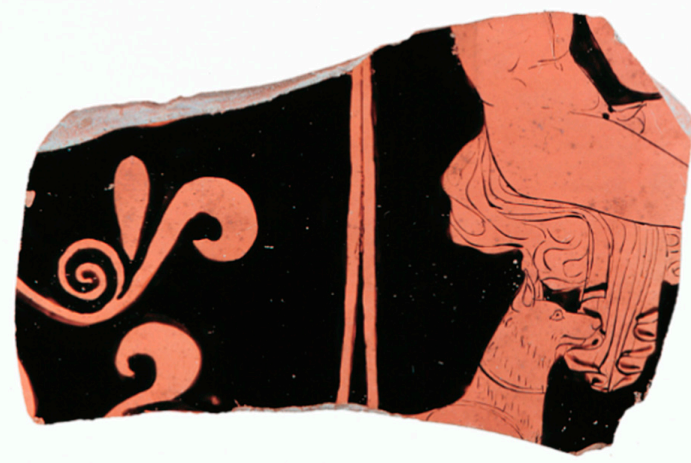

Figure 6. Nude youth with head and tail of dog (APM inv. no. 2501); vase fragment; Tarentum, Southern Italy; ca. fourth century. Photo by Michiel Bootsman; image courtesy of the Allard Pierson Museum, Amsterdam.

39 E.g., the krater by the Pan Painter depicting the death of Actaeon, MFA 10.185, ca. 470 (BAPD 206276).

40 A similar scene is depicted on a seal in the Museum of Fine Arts, Boston (99.356) dated to the early fifth century. Dogs also scratch the ground in order to raise a scent. This is well depicted on a cup dated to 500-450 and attributed to the Onesimos Painter in the same museum (95.27, BAPD 203223). 


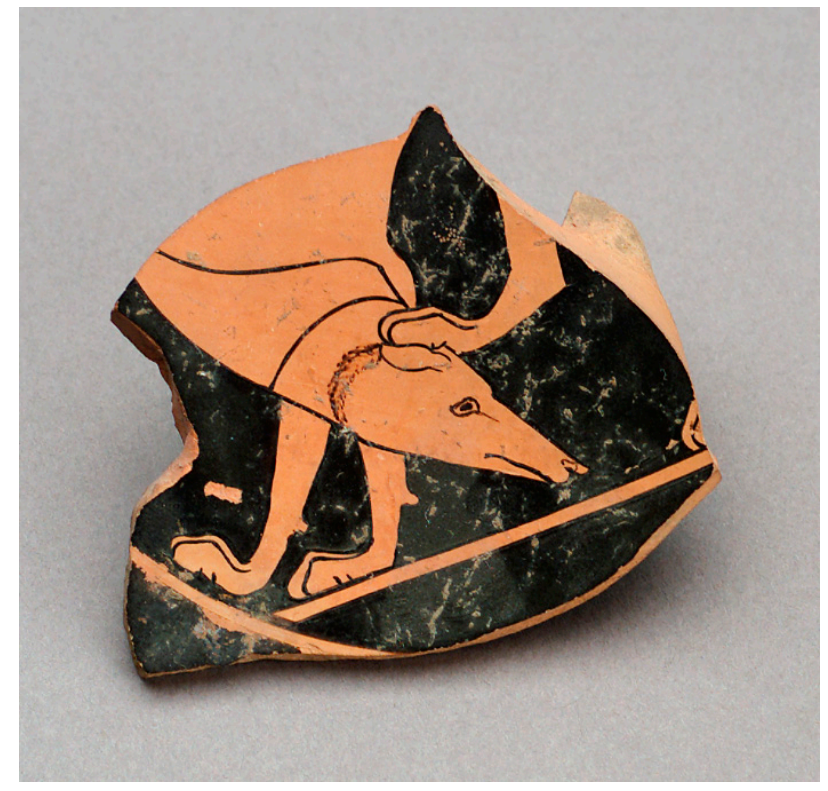

Figure 7. Dog scratching itself (MFA acc. no. 2001.171); kylix fragment; Euergides Painter, ca. 500. Image courtesy of the Museum of Fine Arts, Boston.

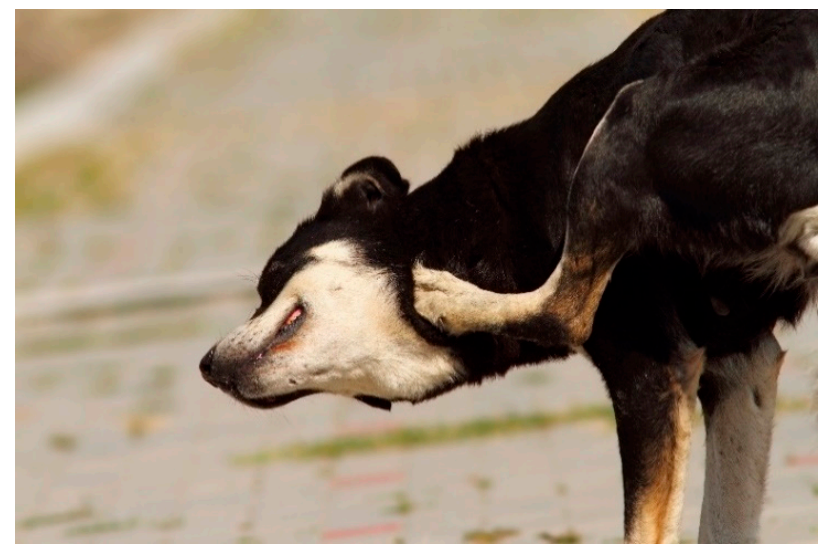

Figure 8. Source: Shutterstock 226564546.

Other scenes portray more complex body language and its accompanying emotions, usually when dogs meet each other or when dogs interact with humans. Two vases are especially expressive of such behavior. An askos dating from 550 to 500 depicts several dogs. Two, on the shoulder, are little more than decorative filler (Figure 9). The body of the vase, however, shows three other dogs in a subfield that normally do not attract much attention (Figures 10 and 11 ) ${ }^{41}$ In fact, however, it is a close study of three dogs in postures based on common canine behaviors, for they are engaged in a typical dominance meeting (Figure 12). The dog in the middle on the Zurich vase stands between the dogs who accompany two male figures approaching one another. Note its body language: tail down, head down in submission, avoidance of eye contact. Compare this to the "Anxious and Nervous" or "Frightened" postures in Figure 5. Both flanking dogs to the left and right are dominant, with their heads held above their cringing subordinate. Note as well the upright tail and erect posture of the dog to the right.

41 I am deeply indebted to Martin Bürge, curator of the Archäologische Sammlung at the University of Zurich, who not only issued permission to use images, but also had new photographs taken to provide the views presented here. 


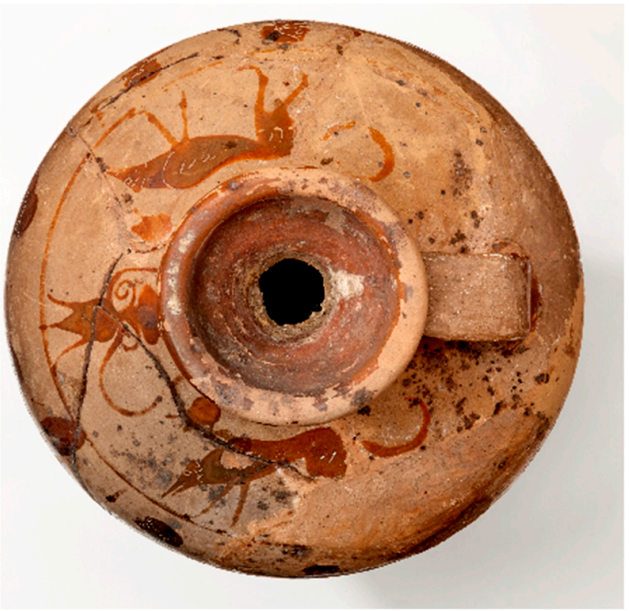

Figure 9. Frieze of dogs (Archäologische Sammlung der Universität Zürich inv. no. 473). Photo: Frank Tomio, image courtesy of the Archäologische Sammlung.

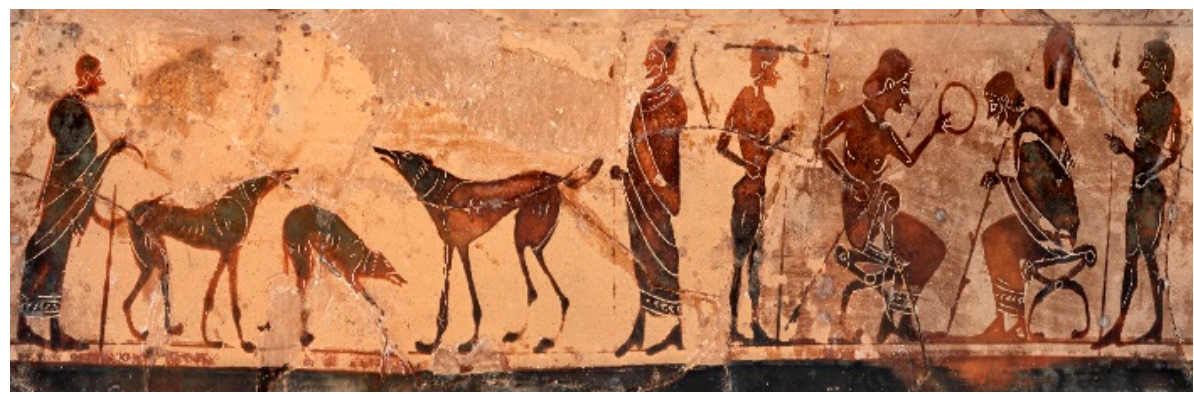

Figure 10. Detail of Figure 9.

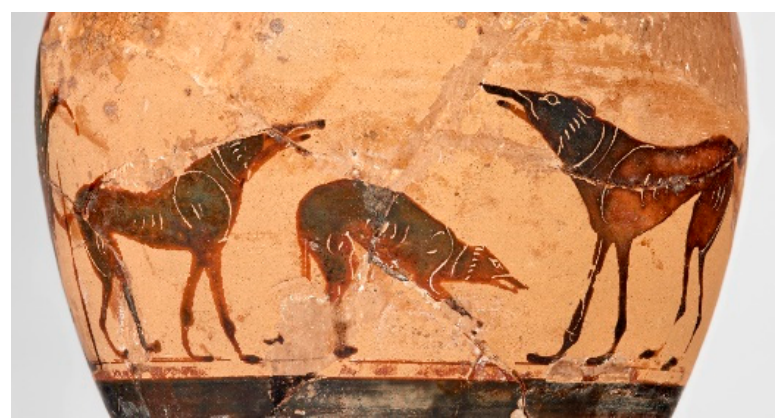

Figure 11. Detail of Figure 9.

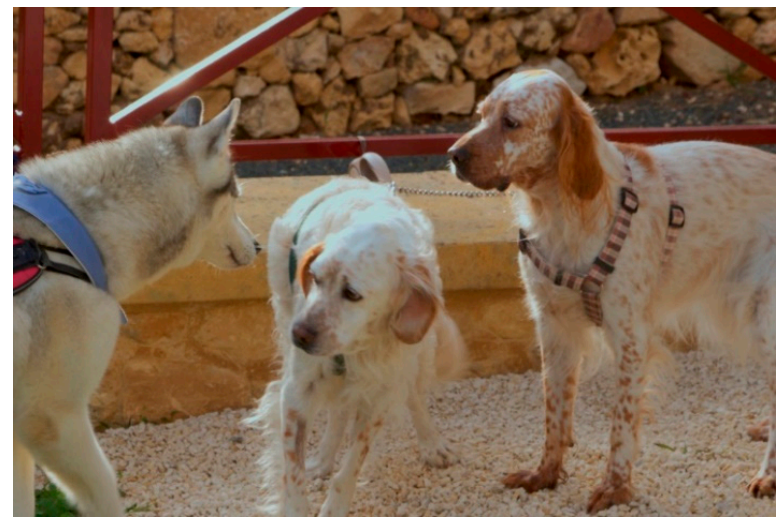

Figure 12. Source: Shutterstock 1496835971. 
Another canine social action very familiar to dog owners is the play posture, or play bow, as illustrated in Figure 13. It is marked by an arched back with the front paws extended and the dog's hindquarters elevated, erect ears, and open mouth. It is commonly seen as an invitation to play when two dogs meet. Ancient painters knew it well, as is shown in an engraving after a vase in the Canino collection (Figure 14). ${ }^{42}$

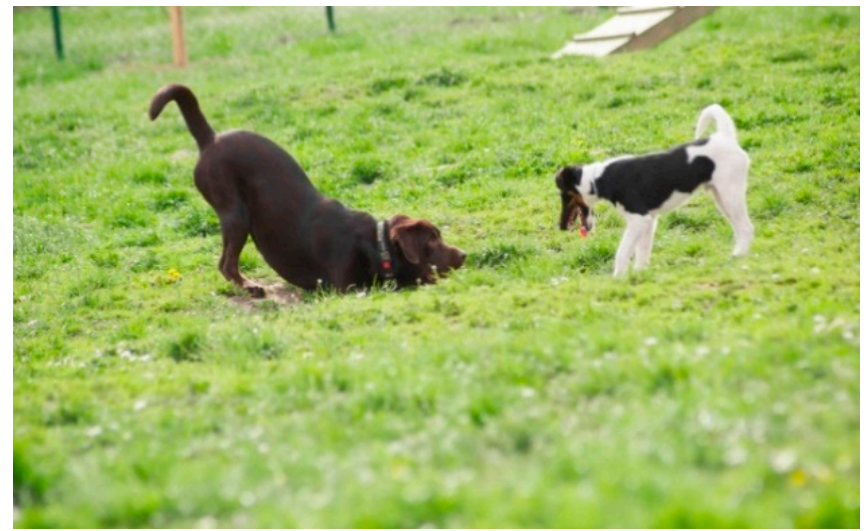

Figure 13. Source: iStock 90187235.

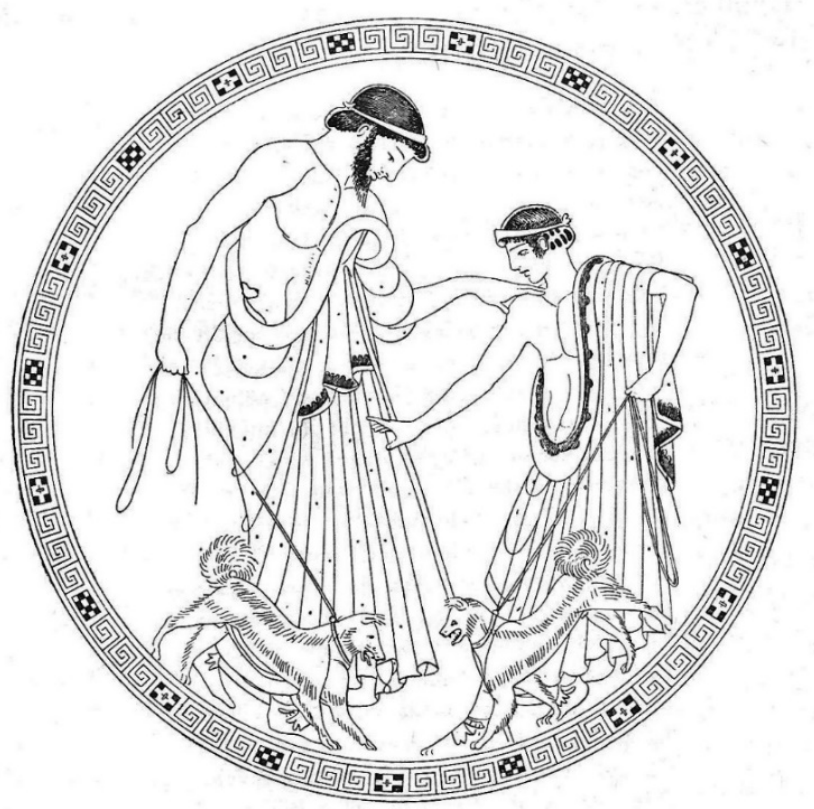

Figure 14. After (Keller [1909] 1913, 1.93, fig. 35) from the Canino collection.

Other vases depict canine behaviors in scenes involving both dogs and humans. Figure 15 has been well known around the world since 1900, when it became the symbol of the Radio Corporation of America. The dog, named Nipper, is listening to an early phonograph and has its head cocked to one side, a canine posture that often indicates curiosity or heightened interest in something. This same behavior is depicted in a warrior's departure vase by Kleophrades (Figure 16) where a dog looks curiously at the figure to the right.

42 (Keller [1909] 1913, 1.93) states that this engraving is "nach Roulez", Moore (2008, fig. 14) shows this engraving and a comparandum by the Brygos Painter, fig. 15. I have been unable to find further information as to its current location as it does not seem to appear in the BAPD. Note the coins of Cyzicus, where a dog is curiously shown in the play position above a tuna fish. 


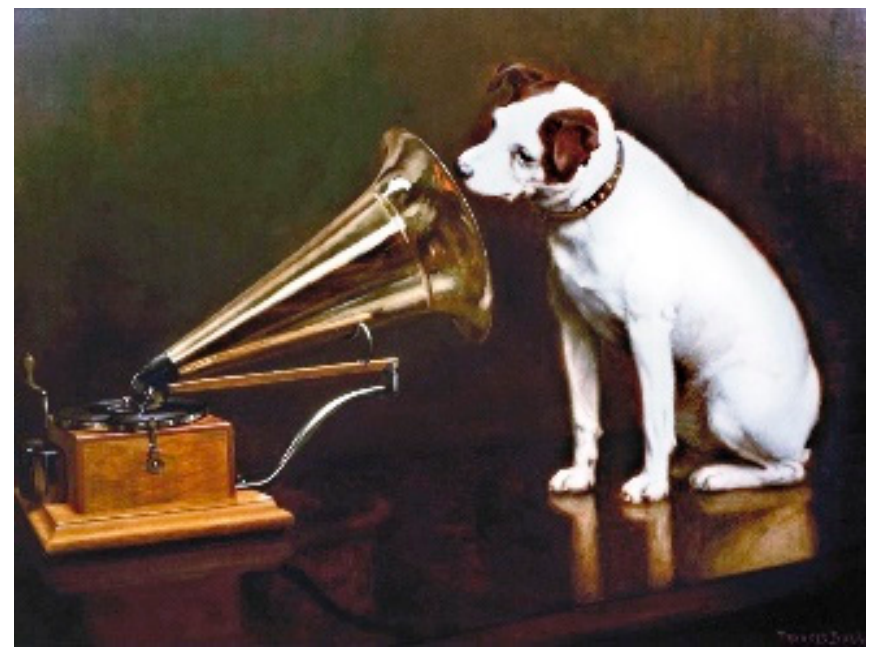

Figure 15. “His Master's Voice” Francis Barraud, 1898. Public Domain, via Wikimedia Commons.

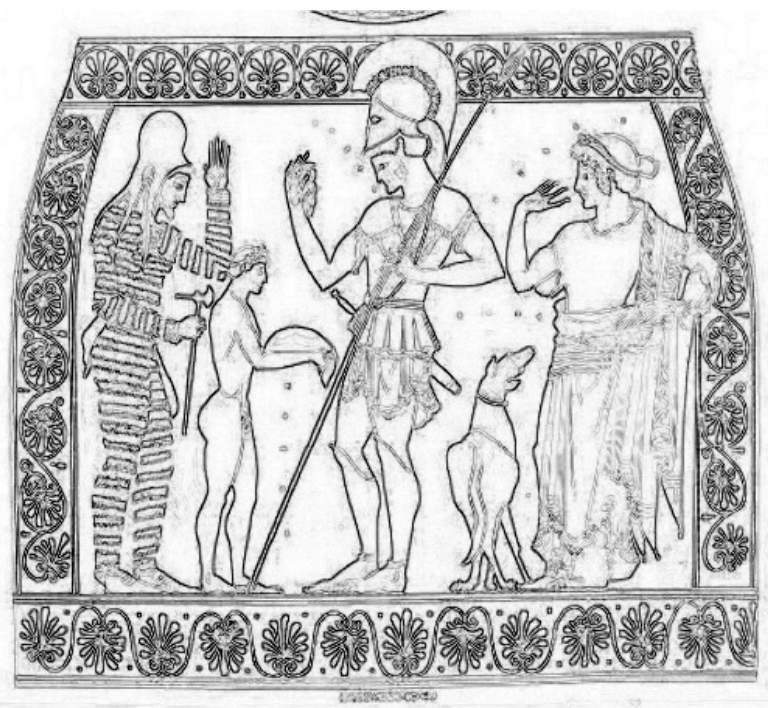

Figure 16. Wurzburg, Universität, Martin von Wagner Museum L507, Kleophrades, ca. 500. After (Furtwängler and Reichhold [1904] 1932, pl. 103; Mayor et al. 2014, fig. 13).

Dogs often raise a front paw when excited and when asking for attention or a treat (Cf. Figure 5, "Excited"). Humans, capitalizing on this natural gesture, have "taught" dogs the "give me your paw" trick for millennia, as demonstrated on a vase by the Triptolemos painter (BAPD 8843, formerly of the Hunt Collection; Pevnick 2014, fig. 2). Curiously, elsewhere on the same vase, a rebellious dog bites a youth in the upper thigh while defecating, striking a pose that could be seen as a parody if we view the youth as failing quite dramatically at teaching the dog to "sit". ${ }^{43}$

We turn now to depictions of dogs using their senses when interacting with humans. Above all else, dogs sniff. It is their primary way of knowing the world. In a black-figured vase dating to 575-525 (Vatican City, Museo Gregoriano Etrusco Vaticano, 17829, attr. to Group E by Beazley, BAPD 301064), the artist depicted a homoerotic courting scene composed of three pairs of lovers, set in the gymnasium.

43 Cf. (Pevnick 2014, fig. 4), where a solitary dog under the handle of a cup in the National Museum of Athens raises its paw as it defecates. Cf. also (Haworth 2018, pp. 18-19). The vignette of a defecating dog is not unheard of in fine art. D'Elia (2005), who was unaware of the Greek examples collected by Pevnick, discusses examples found in the art of Titian (Woodcut: "The Submersion of Pharaoh's Army in the Red Sea"), Dürer (woodcut: The Visitation), and Rembrandt (etching: The Good Samaritan Bringing a Wounded Man to an Inn"), among others. 
The artist inserts a bit of humor into the scene through the natural behavior of two dogs. To the right, an erastes courts his eromenos with a rooster. In the center scene, the erastes holds his young eromenos' chin with his left hand and makes the traditional gesture toward the youth's genitals with his right. Below, however, the older man's dog sniffs the youth's genital area just as, to the left, a dog sniffs the buttocks area of an erastes, who has his back turned to it. Thus, the natural behavior has been turned into a humorous commentary on the nature of the scene being depicted, especially because $\kappa u ́ \omega v$ was a euphemism for referring to the penis (Haworth 2018, p. 10 with note 22).

In addition to using their noses, dogs communicate with each other, and especially with humans, visually. Recent research has centered on the fact that dogs naturally look at their masters, reading their faces for directions and guidance. Dogs continually look up at or back to their humans, seeking things such as reassurance, clues as to the master's wishes, and help in solving problems. A common manifestation of this behavior shows the dog looking back over its shoulder and countless vases show dogs, who naturally trot ahead, doing just this. Cleverly contrived experiments have shown, for example, that when dogs want something they constantly look back and forth from the humans to the desired object, and it is hypothesized that this trait, not present in hand-reared wolves, is a factor of the dog's coevolution with humans. ${ }^{44}$ The reader will recall from above that this behavior is cited by Xenophon as the sign of a good hunting dog. Of special interest is the fact that when dogs look to us, they focus on our faces and especially on our eyes (Gácsi et al. 2004). They even share the human trait of left-gaze bias, i.e., they focus on the right side of the face of the one being observed, just as humans do when viewing one another (Guo et al. 2009). None of this went unnoticed by Greek artists. If one draws a line from the eyes of a dog on a Greek vase to the human at whom it is staring, the line most commonly goes to the human's face and eyes. The reader can do this on several figures accompanying this article.

One remarkable exception is found in a vase from the Allard Pierson Museum collection. The artist has used the looking back gesture but has done so to humorous advantage. The dog, having passed by the herm, looks back at it, almost as if in surprise, looking at its enormous erection (Figure 17). The canine is no idle participant in the scene. Rather, the artist has used it, and its natural behavior, to alter what otherwise might be a stock scene. Once this alteration has been noticed, then, the imploring gesture of the man that is often depicted in homoerotic scenes adds a certain amount of humor to an otherwise standard scene. ${ }^{45}$

Finally, dogs respond to humans when they extend their hand, often to point at an object. Compare Figure 18 where the master extends his hand to get the attention of the dog, who dutifully looks up at its master. This is a common interaction between human and canine and is a prelude to several behaviors such as capturing the dog's attention before issuing a command such as "sit". An extended hand can also be a gesture of affection and is common on stelae where young men apparently bid farewell to their canine companion, often holding out a morsel as a treat. ${ }^{46}$ The well-known but post-Classical (ca. 375) Moschion stela provides an excellent representation of such scenes (Figure 19).

44 The literature is vast, but the consensus of opinion and further bibliography can be found in (Coren 2000; Hare et al. 2002; Hare and Tomasello 2005; Johnston et al. 2016; Kaminski and Nitzschner 2013; Lakatos et al. 2012; Miklósi 2003).

45 The gesture is found as early as Homer's Iliad 1.500-502 where Thetis beseeches Zeus to help Achilles (Boegehold 1999, p.'19, figs. 9, 12). Its use in homoerotic scenes can be seen on Museo Gregoriano Etrusco Vaticano 17829, mentioned above (Dover 1989, ill. B76 and cf. B75), and vase illustrations in (Hubbard 2003, pp. 6, 12d).

46 The gesture appears on vases and stelae alike. Excellent examples of stelae can be found in (Ridgway 1971, figs. 1-3). Vases: Berkeley (CA), Phoebe Apperson Hearst Mus. of Anthropology, 8.921 (BAPD 203994); Rome, Accademia di Lincei, 2478 (BAPD 207462); Wurzburg, Universitat, Martin von Wagner Mus., 218 (BAPD 301643). The "farewell" gesture is also used between humans as in Figure 8, where the man reaches out to a young child, by whom a dog stands. That the dog's gaze is fixed on the child, and may be licking his face, may be a clue as to which of the two humans has died. Ridgway's copious notes list many comparanda. 


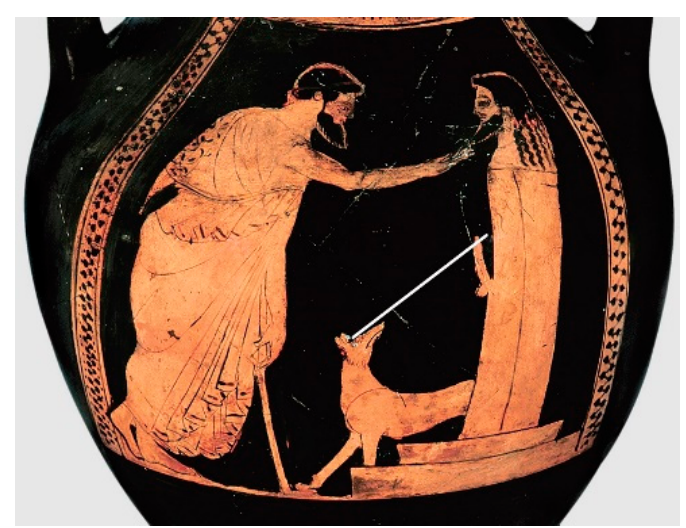

Figure 17. Allard Pierson Museum, 14.225, attr. to Tyszkiewicz Painter; Attic, red figure, 500-450. Used with permission.

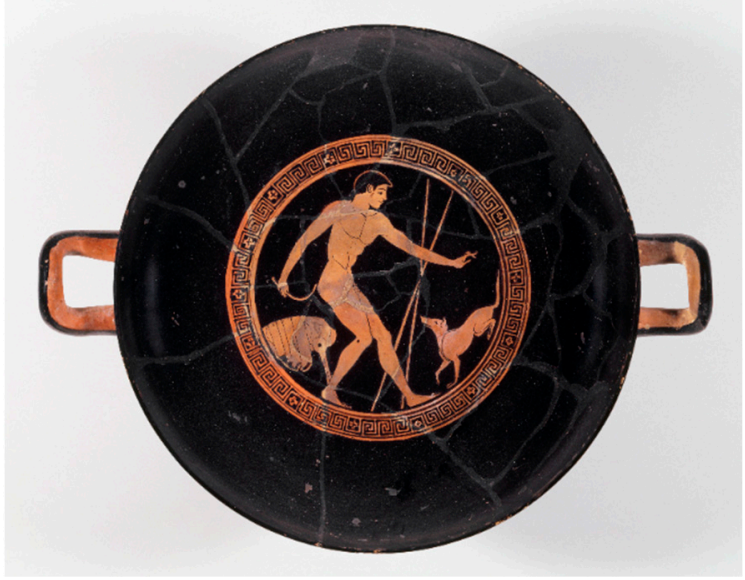

Figure 18. An athlete and his dog. (Museum of Fine Arts, Boston acc. No. 01.8038) Kylix interior; Brygos Painter, 500-450. Image courtesy of the Museum of Fine Arts, Boston.

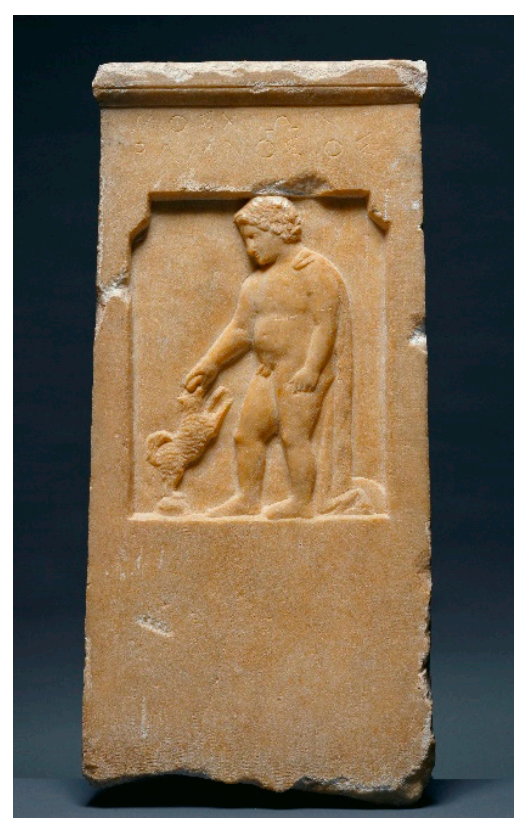

Figure 19. Moschion stela. The J. Paul Getty Museum, Villa Collection, Malibu, California, 73.AA.117. Digital image courtesy of the Getty's Open Content Program. 
I would like to end with a final example of Athenian artists' careful attention to canine body language. The name vase of the Dokimasia Painter depicts a music lesson (Figures 20 and 21). To the left of the pillar, i.e., indoors, we see a seated figure (the teacher?) and two musicians. Such scenes are quite common on vases, depicting the education of a young Athenian male. However, to the right of the pillar, outdoors, we see the saddest dog in Athens, sitting dejectedly at the feet of a man who is probably the boy's paedagogos. The dog's hunched over body and downcast head clearly announce his sadness at being left outdoors while his master takes his lesson. Once again, the artist's rendering of the dog's body language adds a certain amount of pathos mixed, perhaps, with a touch of humor.

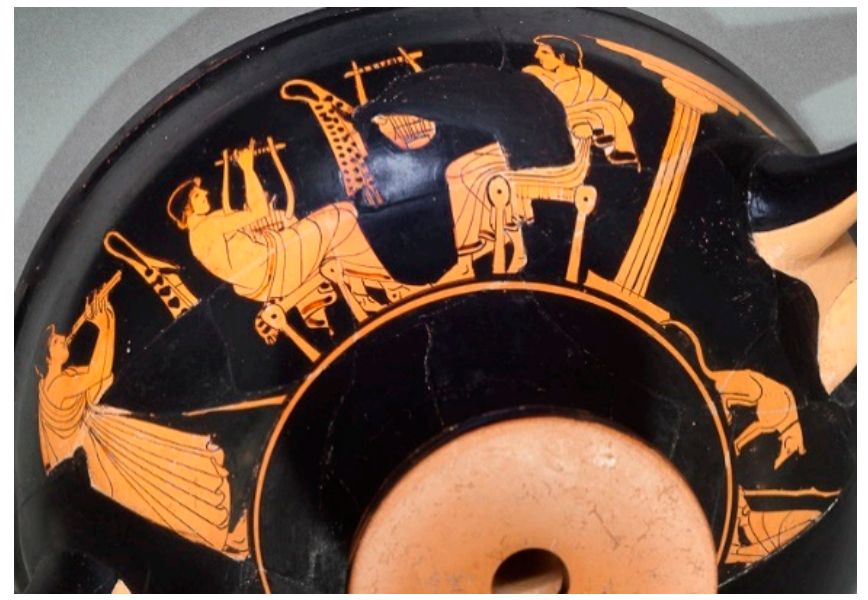

Figure 20. Mead Museum, Amherst College, 1962.74, Dokismasia Painter, 500-450. Used with permission.

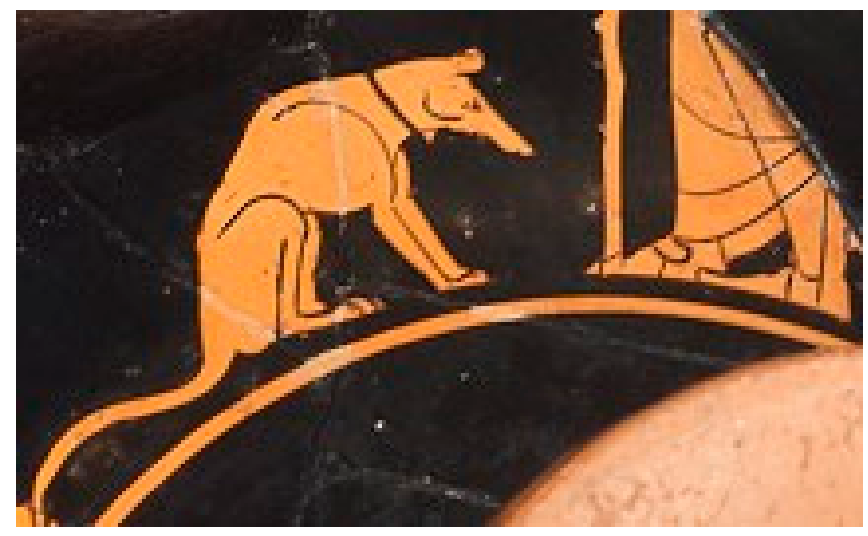

Figure 21. Detail of Figure 20.

\section{Conclusions}

The evidence adduced seems, then, to support a gradual strengthening of the canine/human dynamic from the earliest Greeks to those of the Classical age, as demonstrated both in both the wealth of vocabulary concerning dogs' actions and in their increased presence in the literature. It is also very obvious that by the end of the black figure period and through the height of the red figure period, artists were paying close attention to the naturalistic behaviors of dogs, often elevating them from mere background figures to creatures whose many gestures and postures warranted careful depiction. In some cases, quite often in scenes depicting canine/human interaction, the presence of the dog and its depicted behavior help frame our reaction to the scene depicted. We can also infer that such depictions were valuable to the people who were commissioning the vases.

It remains to find even more examples of natural canine body language and behavior, as well as determining if the evidence for canines extends to other animals. Such studies might offer insights 
into how accurately artists portrayed them as well as offering evidence for their interaction with humans. A prime candidate for further study is the horse, which is shown in various poses on vases and for whose vocalizations a number of words exist. ${ }^{47}$ Bovines are another frequently depicted animal, yet they too are little studied with this focus in mind. Another potential subject for such studies is the hare. This animal is depicted very often on vases, often as an erotic gift. ${ }^{48}$ We see it interacting with humans in a variety of ways_-in cages, on a leash, and commonly held either by its ears, rear legs, or both. ${ }^{49}$ To what extent are these depictions based on the reality of the animal's behavior? Are the animals depicted exhibiting behaviors of wild hares or of those raised in captivity? Investigations of this nature will help us better understand the true relationship the Greeks had with some of their animals.

Funding: This research received no external funding.

Acknowledgments: The author wishes to thank the anonymous reviewers whose careful reading and bibliographic suggestions were immensely helpful. The author also wishes to express his thanks to Anthony L. Ashley, Jr., DVM, DABVP (Canine and Feline), a veterinarian in private practice who is also staff veterinarian for with the Chattanooga Zoo (Tennessee, USA). Ashley gave generously of his time to serve as a consultant on canine behavior and body language. Thomas Mann, retired reference librarian for the Library of Congress, generously performed detailed searches in over 100 databases for research on the "smarl." Kelly A. Johnson, Veterinary Outreach and Information Resources Librarian at Cornell University provided invaluable bibliographical help on the "submissive smile." Of course, any remaining errors are my own.

Conflicts of Interest: The author declares no conflict of interest.

\section{References}

Boardman, John. 1966. Attic Geometric Vase Scenes, Old and New. JHS 86: 1-5. [CrossRef]

Bodson, Liliane. 1980. Place et fonctions du Chien dans le monde antique. Ethnozootechnie 25: 13-21.

Bodson, Liliane. 1983. Attitudes toward Animals in Greco-Roman Antiquity. International Journal for the Study of Animal Problems 4: 312-20.

Bodson, Liliane. 1990. Nature et statut des animaux de compagnie dans l'antiquité gréco-romaine. In Xes Entretiens de Bourgelat. Lyon: École nationale de Médecine vétérinaire et Fondation Marcel Mérieux, pp. 167-74.

Bodson, Liliane. 2000. Motivations for Pet-keeping in Ancient Greece and Rome: A Preliminary Survey. In Companion Animals and Us: Exploring the Relationships between People and Pets. Cambridge: Cambridge University Press, pp. 27-41.

Boegehold, Alan. 1999. When a Gesture Was Expected: A Selection of Examples from Archaic and Classical Greek Literature. Princeton: Princeton University Press.

Bradshaw, John, and Hellen Nott. 1995. Social and Communication Behaviour of Companion Dogs. In The Domestic Dog: Its Evolution, Behaviour and Interactions with People. Cambridge: Cambridge University Press, pp. 115-30.

Brewer, Douglas, Adrian Phillips, and Terence Clark, eds. 2001. Dogs in Antiquity. Anubis to Cerberus. The Origins of the Domestic Dog. Warminster: Aris \& Phillips.

Broodbank, Cyprian. 2000. An Island Archaeology of the Early Cyclades. Cambridge: Cambridge University Press. Bussitil, J. 1969. The Maltese Dog. GER 47: 88-93.

Campbell, Gordon, ed. 2014. The Oxford Handbook of Animals in Classical Thought and Life. Oxford: Oxford University Press.

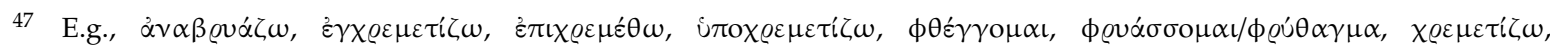

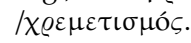

48 See the survey offered by Neils (2014).

49 Cage: Gotha, Scholssmuseum, 48, Euphronius, 550-450 (BAPD 200100). Leash: Worcester (MA) Art Museum, 1936.148, Eretria Painter, 450-400 (BAPD 216970, leash not mentioned in Beazley, confirmed visually by author). Held by ears: New York, Metropolitan Museum GR575, Antiphon Painter, 500-450 (BAPD 203515); St. Petersburg, Heritage Museum (Canino Collection) B2009, Epidromos Painter, 525-475 (BAPD 200982); Hare by rear legs: Adria, Museo Archeolotico Nazionale, 22141, Foundry Painter, 500-450 (BAPD 204368); Rome, Museo Nazionale Etrusco di Villa Giulia, Matsch Painter, 500-450. Hare by front and rear legs and ears; Rome, Mus. Nazionale Etrusco di Villa Giulia 50462, Kleophrades Painter, 500-450 (BAPD 202569), cf. (Manakidou 2015, pp. 130-31 with fig. 1a). 
Clutton-Brock, Juliet. 1995. Origins of the Dog: Domestication and Early History. In The Domestic Dog: Its Evolution, Behaviour and Interactions with People. Cambridge: Cambridge University Press, pp. 7-20.

Coldstream, J. N. 1994. Warriors, Chariots, Dogs and Lions: A New Attic Geometric Amphora. BICS 39: 85-94. [CrossRef]

Coren, Stanley. 2000. How to Speak Dog. New York: Free Press.

D'Elia, Una R. 2005. The Decorum of a Defecating Dog. Print Quarterly 22: 119-32.

Davis, Simon J. M., and François R. Valla. 1978. Evidence for Domestication of the Dog 12,000 Years Ago in the Natufian of Israel. Nature 276: 608-10. [CrossRef]

Day, Leslie Preston. 1984. Dog Burials in the Greek World. AJA 88: 21-32. [CrossRef]

Derr, Mark. 2011. How the Dog Became the Dog. London: Overlook Duckworth.

Dover, Kenneth James. 1989. Greek Homosexuality. Cambridge: Harvard University Press.

Evans, Arthur. 1921. The Palace of Minos at Knossos. London: MacMillan and Co, vol. IV.ii.

Fögen, Thorsten, and Edmund Thomas, eds. 2017. Interactions between Animals and Humans in Graeco-Roman Antiquity. Berlin: Walter De Gruyter.

Fox, M. W. 1970. A Comparative Study of the Development of Facial Expressions in Canids; Wolf, Coyote and Foxes. Behaviour 36: 49-73. [CrossRef]

Franco, Cristiana. 2014. Shameless: The Canine and the Feminine in Ancient Greece: With a New Preface and Appendix. Translated by Matthew Fox. Berkeley: University of California Press.

Furtwängler, Adolf, and Karl Reichhold. 1932. Griechische Vasenmalerei. 3 vols. Munich: Bruchman. First published 1904.

Gácsi, Márta, Ádám Miklósi, Orsolya Varga, József Topál, and Vilmos Csányi. 2004. Are Readers of Our Face Readers of Our Minds? Dogs (Canis Familiaris) Show Situation-dependent Recognition of Human's Attention. Animal Cognition 7: 144-53. [CrossRef]

Galibert, Francis, Pascale Quignon, Christophe Hitte, and Catherine André. 2011. Toward Understanding Dog Evolutionary and Domestication History. Comptes Rendus Biologies 334: 190-96. [CrossRef] [PubMed]

Guo, Kun, Kerstin Meints, Charlotte Hall, Sophie Hall, and Daniel Mills. 2009. Left Gaze Bias in Humans, Rhesus Monkeys and Domestic Dogs. Animal Cognition 12: 409-18. [CrossRef] [PubMed]

Hamilakis, Yannis. 1996. A Footnote on the Archaeology of Power: Animal Bones from a Mycenaean Chamber Tomb at Galatas, NE Peloponnese. ABSA 91: 153-66. [CrossRef]

Harden, Alistair. 2014. Animals in Classical Art. In The Oxford Handbook of Animals in Classical Thought and Life. Oxford: Oxford University Press, pp. 24-60.

Hare, Brian, and Michael Tomasello. 2005. Human-like Social Skills in Dogs? Trends in Cognitive Sciences 9: 439-44. [CrossRef] [PubMed]

Hare, Brian, Michelle Brown, Christina Williamson, and Michael Tomasello. 2002. The Domestication of Social Cognition in Dogs. Science 298: 1634-36. [CrossRef] [PubMed]

Haworth, Marina. 2018. The Wolfish Lover: The Dog as a Comic Metaphor in Homoerotic Symposium Pottery. Archimède: Archéologie et histoire ancienne 5: 7-23. Available online: https://halshs.archives-ouvertes.fr/halshs01825115 (accessed on 23 January 2020).

Hickman, Jane. 2011. The Dog Diadem from Mochlos. In Metallurgy: Understanding How and Learning Why. Philadelphia: INSTAP Academic Press, pp. 91-103.

Hood, Sinclair. 1978. The Arts in Prehistoric Greece. Harmondsworth: Penguin Books.

Horard-Herbin, Marie-Pierre, Anne Tresset, and Jean-Denis Vigne. 2014. Domestication and Uses of the Dog in Western Europe from the Paleolithic to the Iron Age. Animal Frontiers 4.3: 23-31. [CrossRef]

Hubbard, Thomas K., ed. 2003. Homosexuality in Greece and Rome. A Sourcebook of Basic Documents. Berkeley: University of California Press.

Hull, Denison. 1964. Hounds and Hunting in Ancient Greece. Chicago: University of Chicago Press.

Hurwit, Jeffrey. 2002. Reading the Chigi Vase. Hesperia 71: 1-22. [CrossRef]

Johnson, Helen M. 1919. The Portrayal of the Dog on Greek Vases. Classical World 12: 209-13. [CrossRef]

Johnston, Patricia, Attilio Mastrocinque, and Sophia Papaioannou, eds. 2016. Animals in Greek and Roman Religion and Myth. Paper presented at the Symposium Grumentinum Grumento Nova, Potenza, Italy, June 5-7; Newcastle upon Tyne: Cambridge Scholars Publishing.

Kaminski, Juliane, and Marie Nitzschner. 2013. Do Dogs Get the Point? A Review of Dog-human Communication Ability. Learning and Motivation 44: 294-302. [CrossRef] 
Keller, Otto. 1913. Die antike Tierwelt. 2 vols. Leipzig: W. Engelmann. First published 1909.

King, Arthur. 2004. Historical Perspective of Rabies in Europe and the Mediterranean Basin: A Testament to Rabies by Dr. Arthur A. King. Paris: World Organisation for Animal Health.

Kitchell, Kenneth. 2004. Man's Best Friend? The Changing Role of the Dog in Greek Society. In PECUS. Man and Animal in Antiquity. Rome: Swedish Institute, pp. 177-82.

Lakatos, Gabriella, Márta Gásci, József Topál, and Ádám Miklósi. 2012. Comprehension and Utilisation of Pointing Gestures and Gazing in Dog-human Communication in Relatively Complex Situations. Animal Cognition 15: 201-13. [CrossRef] [PubMed]

Lewis, Sian, and Lloyd Llewellyn-Jones. 2018. The Culture of Animals in Antiquity: A Sourcebook with Commentaries. New York: Routledge.

Liston, Maria, Susan Rotroff, and Lynn Snyder. 2018. The Agora Bone Well. Havertown: American School of Classical Studies at Athens.

Lobell, Jarrett A., Eric A. Powell, and Paul Nicholson. 2010. More than Man's Best Friend. Archaeology 63: 26-35.

Manakidou, Eleni. 2015. Eros und siene Tiere auf Attischen Vasen. In Corpus Vasorum Antiquorum, Österreich, Beiheft 2Press, pp. 129-38.

Marinatos, Nano, and Lyvia Morgan. 2005. The Dog Pursuit Scenes from Tell el Dab'a and Kea. In Aegean Wall Painting: A Tribute to Mark Cameron. London: British School at Athens, pp. 119-21.

Mayor, Adrienne. 2014. Animals in Warfare. In The Oxford Handbook of Animals in Classical Thought and Life. Oxford: Oxford University Press, pp. 282-93.

Mayor, Adrienne, John Colarusso, and David Saunders. 2014. Making Sense of Nonsense Inscriptions Associated with Amazons and Scythians on Athenian Vases. Hesperia 83: 447-93. [CrossRef]

Merlen, Rene Henry Albert. 1971. De Canibus. Dog and Hound in Antiquity. London: J.A. Allen.

Miklósi, Ádám. 2003. A Simple Reason for a Big Difference: Wolves Do Not Look Back at Humans, but Dogs Do. Current Biology 13: 763-66. [CrossRef]

Moignard, Elizabeth. 1982. The Acheloos Painter and Relations. ABSA 77: 201-11. [CrossRef]

Moore, Mary B. 2004. Horse Care as Depicted on Greek Vases before 400 B.C. Metropolitan Museum Journal 39: $35-67$. [CrossRef]

Moore, Mary B. 2008. The Hegesiboulos Cup. Metropolitan Museum Journal 43: 11-37. [CrossRef]

Morey, Darcy F. 1994. The Early Evolution of the Domestic Dog. American Scientist 4: 336-47.

Neils, Jenifer. 2014. Hare and the Dog: Eros Tamed. In Approaching the Ancient Artefact. Representation, Narrative, and Function. A Festschrift in Honor of H. Alan Shapiro. Berlin and Boston: De Gruyter, pp. 311-18.

Orphanidis, Laia. 1998. Introduction to Neolithic Figurine Art. Southeastern Europe and Eastern Mediterranean. Athens: Academy of Athens Research Centre for Antiquity, Monograph 4. Available online: https://web.archive.org/ web/20140912175029/http://www.neolithic.gr/pdf/introduction_en.pdf (accessed on 17 October 2019).

Papageorgiou, Irini. 2008. The Mycenaean Golden Kylix of the Benaki Museum: A Dubitandum? Mouseio Benaki 8: 9-37. [CrossRef]

Percy, William Armstrong. 1996. Pederasty and Pedagogy in Archaic Greece. Urbana: University of Illinois Press.

Petrakova, Anna. 2015. The Emotional Dog in Attic Vase-Painting; Symbolical Aspects and instrumental narrative Function. In Corpus Vasorum Antiquorum, Österreich, Beiheft 2griechischen Vasen. Vienna: Austrian Academy of Sciences Press, pp. 292-98.

Pevnick, Seth D. 2014. Good Dog, Bad Dog: A Cup by the Triptolemos Painter and Aspects of Canine Behavior on Athenian Vases. In Athenian Potters and Painters: Volume III. Oxford: Oxbow Books, pp. 155-66.

Rassmussen, Tom. 2016. Interpretations of the Chigi Vase. BABESCH 91: 29-41.

Richter, Gisela. 1970. The Sculpture and Sculptors of the Greeks, 4th ed. New Haven: Yale University Press.

Ridgway, Brunilde Sismondo. 1971. The Man-and-Dog Stelai. JDAI 86: 60-79.

Rombos, Theodora. 1988. The Iconography of Attic Late Geometric II Pottery. Jonsered: Paul Åströms Forlag.

Schmölder-Veit, Andrea. 2008. Zwischen Leben und Tod: Tiere in geometrischen Prothesisbildern. In Mensch und Tier in Der Antike: Grenzziehung und Grenzüberschreitung, Symposion Vom 7. Bis 9. April in Rostock. Wiesbaden: Reichert, pp. 119-37.

Scodel, Ruth. 2005. Odysseus' Dog and the Productive Household. Hermes 133: 401-8.

Serpell, James. 1995a. From Paragon to Pariah: Some Reflections on Human Attitudes to Dogs. In The Domestic Dog: Its Evolution, Behaviour, and Interactions with People. Cambridge: Cambridge University Press, pp. $246-62$. 
Serpell, James, ed. 1995b. The Domestic Dog. Its Evolution, Behaviour and Interactions with People. Cambridge: Cambridge University Press.

Simpson, Barbara. 1997. Canine Communication. Veterinary Clinics of North America: Small Animal Practice 27: 445-64. [CrossRef]

Taliano, Armando. 2012. Stele funeraria con motivo Man and Dog da Kyme eolica. Orizzonti 13: 11-18.

van den Dreisch, Adrian, and Joachim Boessneck. 1990. Die Tierreste von der mykenischen Burg Tiryns bei Nauplion/Peloponnes. In Tiryns: Forschungen und Berichte, XI. Edited by Hans-Joachim Weisshaar. Mainz: Philipp von Zabern, pp. 87-164.

Ventris, Michael, and John Chadwick. 1973. Documents in Mycenaean Greek, 2nd ed. Cambridge: University Press. von Reden, Sitta. 1995. Exchange in Ancient Greece. London: Duckworth.

Wiencke, Martha Heath. 1986. Art and the World of the Early Bronze Age. In The End of the Early Bronze Age in the Aegean. Leiden: Brill, pp. 69-92.

Younger, John. 2005. Sex in the Ancient World from A to Z. Abingdon: Routledge.

(C) 2020 by the author. Licensee MDPI, Basel, Switzerland. This article is an open access article distributed under the terms and conditions of the Creative Commons Attribution (CC BY) license (http://creativecommons.org/licenses/by/4.0/). 